\title{
GRAIN YIELD AND PATH ANALYSIS IN THE EVALUATION OF COWPEA LANDRACES ${ }^{1}$
}

\author{
THAISY GARDÊNIA GURGEL DE FREITAS ${ }^{2}$, PAULO SÉRGIO LIMA E SILVA ${ }^{2}$, JÚLIO CÉSAR DOVALE ${ }^{3}$, \\ ÍTALO NUNES SILVA², EDICLEIDE MACEDO DA SILVA ${ }^{2}$
}

\begin{abstract}
Cowpea is a staple food in the Northeast of Brazil, thus, genetic improvement of this species is important. Samples of cowpea landraces were collected in the State of Rio Grande do Norte, Brazil, and the most promising ones were evaluated in the present study. The objective was to identify the most productive varieties and the characteristics that have greater direct effect on grain yield, for breeding purposes. Twelve landraces were evaluated using a randomized block design with five replications, in two experiments-one in the dry season, and other in the rainy season. However, water irrigation was used in both experiments, due to the almost total absence of rainfall in the rainy season. The Baraúna, and Carnaubais cowpea varieties were the most productive in both experiments. Campo Grande was the best variety found in the experiment carried out in the dry season. José da Penha, Lagoa de Pedra, Umarizal, and Upanema were the best varieties in the experiment carried out in the rainy season. The number of pods per plant was the characteristic that had greater direct effect on grain yield.
\end{abstract}

Keywords: Vigna unguiculata. Traditional varieties. Yield components. Brazilian Northeast crops. Rio Grande do Norte State.

\section{RENDIMENTOS DE GRÃOS E ANÁLISE DE TRILHA NA AVALIAÇÃO DE VARIEDADES TRADICIONAIS DE FEIJÃO-CAUPI}

\begin{abstract}
RESUMO - O feijão-caupi é uma das principais culturas alimentícias do Nordeste brasileiro e, por essa razão, existe interesse em melhorá-la geneticamente. Foram coletadas variedades tradicionais dessa cultura no Estado do Rio Grande do Norte e as mais promissoras foram avaliadas no presente trabalho. Objetivou-se identificar as mais produtivas e distinguir, entre as características avaliadas, a que possui o maior efeito direto sobre o rendimento de grãos, para fins de melhoramento. Doze variedades foram avaliadas em blocos ao acaso com cinco repetições em dois experimentos. Um dos experimentos foi irrigado. O outro experimento foi realizado na época das chuvas, mas requereu irrigação devido à ausência quase que total de chuvas. As variedades Baraúna e Carnaubais foram as mais produtivas nos dois experimentos. No experimento realizado com irrigação foi destaque a variedade Campo Grande. Sob condições de sequeiro (com chuvas) destacaram-se também as variedades José da Penha, Lagoa de Pedra, Umarizal e Upanema. O número de vagens por planta foi o principal caráter a influenciar o rendimento de grãos.
\end{abstract}

Palavras-chave: Vigna unguiculata. Variedades crioulas. Feijão-de-corda. Feijão macassar. Componentes do rendimento.

\footnotetext{
*Corresponding author

${ }^{1}$ Received for publication in $09 / 01 / 2017$; accepted in $12 / 04 / 2018$

Paper extracted from the master dissertation of the first author.

${ }^{2}$ Department of Agronomic and Forestry Sciences, Universidade Federal Rural do Semi-Árido, Mossoró, RN, Brazil; thaisy_gurgel@hotmail.com - ORCID: 0000-0002-8889-4672, paulosergio@ufersa.edu.br - ORCID: 0000-0002-4465-6517, italonunessilva@gmail.com - ORCID: 0000-0003-0954-1260, edicleide.c.c@hotmail.com - ORCID: 0000-0002-3196-6516.

${ }^{3}$ Department of Plant Science, Universidade Federal do Ceará, Fortaleza, CE, Brazil; juliodovale@ufc.br - ORCID: 0000-0002-3497-9793.
} 


\section{INTRODUCTION}

Cowpea (Vigna unguiculata (L.) Walp.) is probably the most important food crop in the state of Rio Grande do Norte ( $\mathrm{RN})$; it is also important for other Brazilian states (FREIRE FILHO, 2011), and other regions of the world (TAN et al., 2012). Data of the Brazilian Institute of Geography and Statistics (IBGE) from 2013 indicate that this species is grown in all municipalities of RN. Cowpea producers use landraces to produce green beans, or dry grains. The low cowpea yields in some regions of $\mathrm{RN}$ is due to the planting of low-yield varieties. Moreover, few research institutions have breeding programs to develop cowpea cultivars (FREITAS et al., 2016) and even fewer companies produce improved cowpea seeds in RN.

Landraces show intermediate yields (BRESEGHELLO; COELHO, 2013), but studies indicate that some landraces may be more productive than improved cultivars (MAKOI; CHIMPHANGO; DAKORA, 2009; PEKSEN, 2004). Therefore, evaluations of landraces can identify those that can be used by farmers and breeding programs (BOUKAR; FATOKUN, 2009; FREIRE FILHO et al., 2012).

Collections and evaluations of seeds of cowpea landraces allow their conservation and identification of the most promising ones to be used by farmers and breeding programs. Studies on cowpea landraces have been conducted in several countries and indicated differences between the landraces for several characteristics (HEGDE; MISHRA, 2009; BERTINI et al., 2010; COBBINAH; ADDO-QUAYE; ASANTE, 2011; YOSEPH, 2014). In these evaluations, it has been possible to identify superior landraces (HEGDE; MISHRA, 2009; BERTINI et al., 2010).

These evaluations can also estimate the correlation between characteristics, which is important for the selection of characteristics that have low heritability or are difficult to measure based on selections of characteristics that have highheritability or are easy to measure. This practice can provide an indirect and early selection of varieties, allowing the efforts to be concentrated on the most promising genotypes (MISHRA; DASH, 2009).

Correlations between characteristics have been estimated for several crop species by different methods, especially through the path analysis proposed by Wright (1921). This analysis shows direct and indirect effects of one characteristic on another. Several studies conducted path analysis on cowpea and indicated that the number of pods per plant, and pod length were the characteristics that have the greatest direct positive effect on the yield of green pods (ALMEIDA et al., 2014; NWOFIA; OGBONNA; AGBO, 2013; SAPARA; JAVIA, 2014; SANTOS et al., 2014); and the number of pods per plant and number of grains per pod were the characteristics that have the greatest direct effects on the dry grain yield (ALMEIDA et al., 2014). However, different results are found according to the group of evaluated genotypes, thus, path analyses with different varieties are necessary.

One random sample of seeds of cowpea landraces was collected in each of 73 municipalities of the State of Rio Grande do Norte, Brazil, that had the largest crop areas with cowpea in 2008. These seeds were evaluated and the 12 most promising ones were used for the present study. The objective was to identify the most productive landraces for dry grains, and the characteristics that have greater direct effect on grain yield, using path analysis.

\section{MATERIAL AND METHODS}

Two experiments were carried out at the Rafael Fernandes Experimental Farm of the Federal Rural University of the Semi-Arid Region (UFERSA), in Mossoró, state of Rio Grande do Norte, Brazil $\left(5^{\circ} 11^{\prime} \mathrm{S}, 37^{\circ} 20^{\prime} \mathrm{W}\right.$, and altitude of 18 $\mathrm{m})$. The first experiment was carried out from August to December 2013, and the second from January to April 2014. According to the Gaussen's bioclimatic classification, the climate of the Mossoró region is 4ath, strongly thermoxeroquimenic, hot tropical, with a long season of marked drought (seven to eight months), and xerothermic index between 150 and 200. The region has maximum average air temperature of 32.1 to $34.5{ }^{\circ} \mathrm{C}$ (June and July are the coldest months); average annual precipitation of $825 \mathrm{~mm}$; increased sunshine period from March to October, with a mean of $241.7 \mathrm{~h}$; and maximum relative air humidity of $78 \%$ in April, and minimum of $60 \%$ in September (CARMO FILHO; OLIVEIRA, 1989). Climatic data recorded during the experiment period were obtained from a weather station at $20 \mathrm{~km}$ from the experiment site (Table 1).

The soil of the experimental area was classified as Red-Yellow Argissolo, according to the Brazilian Soil Classification System (EMBRAPA, 2013), and Ferric Lixisol, according to the Soil Map of the World (FAO, 1988). The soil chemical analyses of the two experiments are presented in Table 1. $\mathrm{P}$ and $\mathrm{K}$ were extracted with a Mehlich 1 extractor solution $\left(0.05 \mathrm{M} \mathrm{HCl}\right.$ in $\left.0.0125 \mathrm{M} \mathrm{H}_{2} \mathrm{SO}_{4}\right)$. $\mathrm{P}$ was determined by colorimetry, and $\mathrm{K}$ by photometry. $\mathrm{Ca}, \mathrm{Mg}$, and $\mathrm{Al}$ were extracted with $1 \mathrm{M}$ $\mathrm{KCl}$. Aluminum was determined by titration with $\mathrm{NaOH}$, and $\mathrm{Ca}$ and $\mathrm{Mg}$ by titration with EDTA.

Sowing fertilization consisted of $30 \mathrm{~kg} \mathrm{ha}^{-1}$ $(1 / 3)$ of the nitrogen (ammonium sulphate), $100 \mathrm{~kg}$ $\mathrm{ha}^{-1}$ of $\mathrm{P}_{2} \mathrm{O}_{5}$ (single superphosphate), and $50 \mathrm{~kg} \mathrm{ha}^{-1}$ $\mathrm{K}_{2} \mathrm{O}$ (potassium chloride). The fertilizers were applied in furrows below and beside the sowing furrows. The remainder $\mathrm{N}$ was applied as topdressing divided equally into two applications after weeding. 
Seeding was manually performed using four seeds per hole, with $1.0 \mathrm{~m}$ between rows and $1.0 \mathrm{~m}$ between plants. The seedlings were thinned at 20 days after sowing, leaving the two largest plants of each hole, making a plant density of 20,000 plants ha ${ }^{-1}$.

A sprinkler system was used for irrigation with the experimental plots arranged parallel to the sprinkler row. The water depth used for the cowpea plants $(5.3 \mathrm{~mm})$ was calculated considering an effective depth of the root system of $0.40 \mathrm{~m}$. Irrigations were carried out every two days, based on the water retained in the soil under a tension of 0.40 $\mathrm{MPa}$. Irrigations were started after sowing and were suspended fifteen days before harvest.

Pests were controlled by using two applications of Deltamethrin $\left(250 \mathrm{ml} \mathrm{ha}^{-1}\right)$, at 7 and 14 days after sowing. Weeds were controlled by two manual weeding, at 20 and 40 days after sowing.

A randomized block design with five replications was used. The evaluated varieties were: Baraúna, Campo Grande, Carnaubais, Ceará Mirim, Itaú, José da Penha, Lagoa de Pedra, Lagoa Salgada, Macaíba, São Tomé, Umarizal, and Upanema. These varieties were named according to the names of the municipalities where they were collected.

Plots consisted of four $6.0 \mathrm{~m}$ long plant rows, and the evaluation area consisted of the two central rows, discarding the plants at the end holes of the rows. The plants of one of these two rows was randomly selected to evaluate green bean yield (data not shown), and the other to evaluate dry grain yield. Three harvests with four-day intervals were performed to evaluate the dry grain yield of the cowpea plants. Number of pods per plant based on pods harvested in the evaluation area, number of grains per pod based on 20-pod samples, 100-grain weight based on five samples, grain length, width, and thickness based on 10-grain samples were also evaluated.

Table 1. Maximum, minimum, and mean air temperatures, global radiation, rainfall, and relative air humidity in Mossoró, state of Rio Grande do Norte, Brazil, from August 2013 to April 2014; and soil chemical analyses of the two experiments (2013 and 2014).

\begin{tabular}{|c|c|c|c|c|c|c|}
\hline \multirow{2}{*}{ Months } & \multicolumn{3}{|c|}{ Air Temperature $\left({ }^{\circ} \mathrm{C}\right)$} & \multirow{2}{*}{$\begin{array}{l}\text { Global radiation } \\
\left(\mathrm{MJ} \mathrm{m}^{-2} \mathrm{dia}^{-1}\right)\end{array}$} & \multirow{2}{*}{$\begin{array}{c}\text { Rainfall depth } \\
(\mathrm{mm})\end{array}$} & \multirow{2}{*}{$\begin{array}{l}\text { Relative Air } \\
\text { Humidity (\%) }\end{array}$} \\
\hline & Max. & Mean & Min. & & & \\
\hline August 2013 & 33.5 & 26.2 & 20.3 & 13.7 & 0.2 & 56.4 \\
\hline September 2013 & 33.8 & 26.7 & 21.2 & 15.7 & 0.4 & 54.8 \\
\hline October2013 & 33.9 & 27.0 & 21.9 & 19.2 & 0.0 & 55.5 \\
\hline November 2013 & 33.8 & 27.2 & 22.4 & 18.4 & 0.1 & 56.9 \\
\hline December 2013 & 34.1 & 27.4 & 22.6 & 16.7 & 0.4 & 59.1 \\
\hline Mean & 33.8 & 26.9 & 21.7 & 16.7 & 0.2 & 56.5 \\
\hline January 2014 & 34.6 & 27.7 & 22.7 & 16.0 & 0.1 & 56.5 \\
\hline February 2014 & 34.6 & 27.7 & 22.7 & 15.3 & 1.4 & 57.0 \\
\hline March 2014 & 33.8 & 27.6 & 23.0 & 19.6 & 4.4 & 60.5 \\
\hline April 2014 & 32.9 & 27.0 & 23.0 & 18.2 & 6.3 & 64.6 \\
\hline Mean & 33.9 & 27.5 & 22.9 & 17.3 & 3.1 & 59.7 \\
\hline \multicolumn{5}{|c|}{ Soil chemical properties } & 2013 & 2014 \\
\hline \multicolumn{5}{|c|}{$\mathrm{pH}$ in water } & 6.3 & 7.2 \\
\hline \multicolumn{5}{|c|}{ Electrical conductivity $\left(\mathrm{dS} \mathrm{m}^{-1}\right)$} & 0.00 & 0.15 \\
\hline \multicolumn{5}{|c|}{ Organic matter $\left(\mathrm{g} \mathrm{kg}^{-1}\right)$} & 10.6 & 13.24 \\
\hline \multicolumn{5}{|c|}{$\mathrm{P}\left(\mathrm{Mg} \mathrm{dm}^{-3}\right)$} & 5.5 & 17.9 \\
\hline \multicolumn{5}{|c|}{$\mathrm{K}^{+}\left(\mathrm{Mg} \mathrm{dm}^{-3}\right)$} & 75.7 & 161.7 \\
\hline \multicolumn{5}{|c|}{$\mathrm{Na}^{+}\left(\mathrm{Mg} \mathrm{dm}{ }^{-3}\right)$} & 15.9 & 32.5 \\
\hline \multicolumn{5}{|c|}{$\mathrm{Ca}^{2+}\left(\mathrm{cmol}_{\mathrm{c}} \mathrm{dm}^{-3}\right)$} & 1.9 & 3.2 \\
\hline \multicolumn{5}{|c|}{$\mathrm{Mg}^{2+}\left(\mathrm{cmol}_{\mathrm{c}} \mathrm{dm}^{-3}\right)$} & 0.66 & 1.70 \\
\hline \multicolumn{5}{|c|}{ Exchangeable acidity $\left(\mathrm{Al}^{3+}\right)\left(\mathrm{cmol}_{\mathrm{c}} \mathrm{dm}^{-3}\right)$} & 0.0 & 0.0 \\
\hline \multicolumn{5}{|c|}{ Potential acidity $(\mathrm{H}+\mathrm{Al})\left(\mathrm{cmol}_{\mathrm{c}} \mathrm{dm}^{-3}\right)$} & 1.07 & 0.00 \\
\hline \multicolumn{5}{|c|}{ Sum of bases $\left(\mathrm{cmol}_{\mathrm{c}} \mathrm{dm}^{-3}\right)$} & 2.82 & 5.45 \\
\hline \multicolumn{5}{|c|}{ Cation exchange capacity (CEC) at $\mathrm{pH} 7.0\left(\mathrm{cmol}_{\mathrm{c}} \mathrm{dm}^{-3}\right)$} & 2.82 & 5.45 \\
\hline \multicolumn{5}{|c|}{ Effective CEC $\left(\mathrm{cmol}_{\mathrm{c}} \mathrm{dm}^{-3}\right)$} & 3.90 & 5.45 \\
\hline \multicolumn{5}{|c|}{ Base saturation $(\%)$} & 72 & 100 \\
\hline \multicolumn{5}{|c|}{ Al saturation $(\%)$} & 0 & 0 \\
\hline \multicolumn{5}{|c|}{ Exchangeable sodium percentage (\%) } & 2 & 3 \\
\hline
\end{tabular}


Individual analyses of variance were performed for each experiment considering the model $Y_{i k}=\mu+g_{i}+b_{k}+\varepsilon_{i k}$, wherein $Y_{i k}$ is the observed value for a given characteristic of the $i$-th variety in the $k$-th repetition; $\mu$ is the overall mean for the character; $g_{i}$ is the effect of the $i$-th variety (fixed effect), with $g \sim \mathrm{NID}\left(\mathrm{g}, \mathrm{g}^{2}\right) ; b_{k}$ is the $k$-th repetition effect (random effect), with $b \sim$ NID ( 0 , $\sigma^{2}$ ); $\varepsilon_{i k}$ is the random error effect associated with the observation $i k$, with $\varepsilon \sim \operatorname{NID}\left(0, \sigma^{2}\right)$.

Joint analyses of variance were performed for the evaluated characteristics considering the model $Y_{i j k}=\mu+\alpha_{i}+\beta_{j}+(\alpha \beta)_{i j}+\varepsilon_{i j k}$, wherein $Y_{i k}$ is the value observed for a given characteristic of the $i$ th variety, in the $j$-th experiment, and $k$-th replication; $\mu$ is the overall mean for the character; $\alpha i$ is the effect of the $i$-th variety $(i=1,2, \ldots, 12)$ (fixedeffect), with $\alpha \sim \mathrm{NID}\left(\mathrm{g}, \mathrm{g}^{2}\right) ; \beta j$ is the effect of the $j$-th experiment $(j=1,2)$, (random effect), with $a \sim \mathrm{N}(0$, $\left.\sigma^{2}{ }_{\mathrm{a}}\right) ;(\alpha \beta) i j$ is the effect of the interaction of the $i$-th variety with the $j$-th experiment (random effect), with $g a \sim$ NID $\left(0, \sigma_{\text {ga }}^{2}\right)$; $\varepsilon i k$ is the random error effect

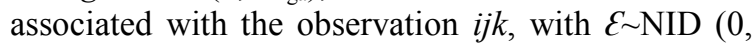
$\left.\sigma^{2}\right)$. The means were compared by the Scott and Knott (1974) test at 5\% probability when the F test was significant in the analysis of variance. The data were subjected to Bartlett homogeneity of variance test (NOGUEIRA; PEREIRA, 2013) before the analysis of variance.

Analyzes of variance were performed using the Statistical Analysis System (SAS 9.1) program (SAS Institute 2003). The multicollinearity diagnosis, and path analysis were performed using the Computational Application for Genetics and Statistics (Genes Program) (CRUZ, 2013).

In the path analysis, the degree of multicollinearity of the $X^{\prime} X$ matrix was established based on its condition number $(\mathrm{CN}$, ratio between the highest and the lowest eigenvalues of the matrix), and the value of the determinant of the correlation matrix between the studied characteristics. The multicollinearity does not cause problems to the path analysis when the $\mathrm{CN}$ is lower than 100 (TOEBE; CARGNELUTTI FILHO, 2013), and values of determinants close to zero indicate a strong association between the characteristics studied, which could bias the estimates. Preliminary analyses were carried out and multicollinearity was found for both experiments, in $2013(\mathrm{CN}=175.46$, variance inflation factor (VIF) above 10 units and determinant $\left.=1.83 \times 10^{-6}\right)$, and in $2014(\mathrm{CN}=122.51$, VIF above 10 units, and determinant $\left.=3.42 \times 10^{-7}\right)$. According to Montgomery and Peck (1981), these are moderate to strong multicollinearities, thus, path analysis was performed under multicollinearity, using a similar procedure to ridge regression analysis (CARVALHO; CRUZ, 1996). Different from conventional path analysis, path analysis under multicollinearity introduces the $k$ constant in the $\mathrm{X}^{\prime} \mathrm{X}$ correlation matrix to reduce the variance associated with the least square estimator of the path analysis (CARVALHO; CRUZ, 1996). Thus, the system of normal equations $X^{\prime} X \beta=X^{\prime} Y$ becomes $\left(X^{\prime} X+k\right) \beta$ $+\mathrm{X}^{\prime} \mathrm{Y}$. Twenty-one values of $\mathrm{k}(\mathrm{k}=0.00,0.05 \ldots$ 1.00) were tested. The lowest of these values $\left(5.83 \times 10^{-2}\right)$ for the first test and $6.40 \times 10^{-2}$, which stabilized the path coefficients, were chosen, as recommended by Carvalho and Cruz (1996).

\section{RESULTS AND DISCUSSION}

The varieties $(V)$, experiments $(\mathrm{E})$, and $\mathrm{V} \times \mathrm{E}$ interaction had significant effects on grain yield (Table 2). Baraúna, Campo Grande, and Carnaubais were the most productive landraces in the experiment carried out in the dry season (2013), presenting similar results and differing from the other landraces, which also had similar results among themselves (Table 3). Baraúna, Carnaubais, Campo Grande, José da Penha, Lagoa de Pedra, Umarizal, and Upanema were the most productive landraces in the experiment carried out in the rainy season (2014) (Table 3). The Umarizal and Upanema landraces had similar yields in both experiments, whereas the yield of the other varieties was higher in the first experiment (2013) (Table 3). Therefore, the time of sowing should be considered for the choice of the landrace. Freire Filho et al. (2003) found that there are varieties of cowpeas specifically adapted to better-quality, however unstable environments; and varieties that can be grown in all environments.

The areas of the two experiments were near each other, but some soil chemical characteristics in the experiment carried out in the rainy season (2014) were better (Table 1). Grain yields were higher for ten varieties in the first experiment (2013), and similar for the other two varieties in both experiments, indicated that the climatic conditions were more favorable to the crop in the first experiment (Table 1). Moreover, the genotypes that better fixed atmospheric $\mathrm{N}_{2}$ were those that presented higher grain yields and biomasses (BELANE; DAKORA, 2010). Several abiotic factors can affect nitrogen fixation (AL-FALIH, 2002), which depends on the genotype and the year of evaluation (BELANE; DAKORA, 2010). Therefore, the conditions of the first experiment (2013) may have been favorable to the crop and the nitrogen fixing bacteria. 
T. G. G. FREITAS et al.

Table 2. Joint analysis variance for data of grain yield and yield components of cowpea landraces in two experiments.

\begin{tabular}{|c|c|c|c|c|c|}
\hline Source of variation & $\begin{array}{l}\text { Degrees of } \\
\text { freedom }\end{array}$ & $\begin{array}{l}\text { Grain yield } \\
\left(\mathrm{kg} \mathrm{ha}^{-1}\right)\end{array}$ & $\begin{array}{c}\text { Number of pods } \\
\text { per plant }\end{array}$ & $\begin{array}{c}\text { Number of } \\
\text { grains per pod }\end{array}$ & $\begin{array}{c}\text { 100-grain } \\
\text { weight } \\
\text { (g) }\end{array}$ \\
\hline & & \multicolumn{4}{|c|}{ Mean squares } \\
\hline Varieties (V) & 11 & $279525.1 * *$ & $133.2 * *$ & $1.6 \mathrm{~ns}$ & $60.41 * *$ \\
\hline Experiments (E) & 1 & $10673073.1 * *$ & $2.004 .1 * *$ & $7.2 * *$ & $25.47 * *$ \\
\hline $\mathrm{V} \times \mathrm{E}$ & 11 & $200688.5 * *$ & $29.5 \mathrm{~ns}$ & $4.6^{* *}$ & $3.49 * *$ \\
\hline Blocks within E & 8 & $165483.2 *$ & $51.4 * *$ & $1.3 \mathrm{~ns}$ & $2.59 * *$ \\
\hline Residue & 88 & 64603.6 & 18.7 & 0.9 & 0.75 \\
\hline CV $(\%)$ & & 24.1 & 22.1 & 6.7 & 4.28 \\
\hline
\end{tabular}

Table 3. Grain yield and number of pods per plant of cowpea landraces in two experiments ${ }^{1}$.

\begin{tabular}{|c|c|c|c|c|c|}
\hline \multirow[t]{3}{*}{ Varieties } & \multicolumn{2}{|c|}{ Grain yield $\left(\mathrm{kg} \mathrm{ha}^{-1}\right)$} & \multicolumn{3}{|c|}{ Number of pods per plant } \\
\hline & \multicolumn{2}{|c|}{ Experiments } & \multicolumn{2}{|c|}{ Experiments } & \multirow[t]{2}{*}{ Mean } \\
\hline & 2013 & 2014 & 2013 & 2014 & \\
\hline Baraúna & $1467 \mathrm{Aa}$ & $881 \mathrm{Ab}$ & 23.2 & 13.6 & $18.4 \mathrm{C}$ \\
\hline Campo Grande & $1636 \mathrm{Aa}$ & $426 \mathrm{Bb}$ & 26.8 & 21.6 & $24.2 \mathrm{~A}$ \\
\hline Carnaubais & $1709 \mathrm{Aa}$ & $976 \mathrm{Ab}$ & 26.0 & 23.0 & $24.5 \mathrm{~A}$ \\
\hline Ceará Mirim & $1304 \mathrm{Ba}$ & $599 \mathrm{Bb}$ & 28.0 & 19.4 & $23.7 \mathrm{~A}$ \\
\hline Itaú & $1291 \mathrm{Ba}$ & $556 \mathrm{Bb}$ & 23.6 & 17.8 & $20.7 \mathrm{~B}$ \\
\hline José da Penha & $1342 \mathrm{Ba}$ & $923 \mathrm{Ab}$ & 22.8 & 17.2 & $20.0 \mathrm{~B}$ \\
\hline Lagoa de Pedra & $1293 \mathrm{Ba}$ & $926 \mathrm{Ab}$ & 24.6 & 18.0 & $21.3 \mathrm{~B}$ \\
\hline Lagoa Salgada & $1137 \mathrm{Ba}$ & $597 \mathrm{Bb}$ & 23.0 & 16.5 & $19.8 \mathrm{~B}$ \\
\hline Macaíba & $1141 \mathrm{Ba}$ & $343 \mathrm{Bb}$ & 22.0 & 7.8 & $14.9 \mathrm{D}$ \\
\hline São Tomé & $1353 \mathrm{Ba}$ & $687 \mathrm{Bb}$ & 18.8 & 10.6 & $14.7 \mathrm{D}$ \\
\hline Umarizal & $1336 \mathrm{Ba}$ & $1063 \mathrm{Aa}$ & 23.8 & 12.5 & $18.2 \mathrm{C}$ \\
\hline Upanema & $1253 \mathrm{Ba}$ & $1126 \mathrm{Aa}$ & 20.8 & 7.3 & $14.1 \mathrm{D}$ \\
\hline Mean & - & - & $23.2 \mathrm{a}$ & $15.4 \mathrm{~b}$ & - \\
\hline $\mathrm{CV} \%$ & & & & 22.1 & \\
\hline
\end{tabular}

${ }^{1}$ Means followed by the same uppercase letter in the columns, or same lowercase letter in the rows belong to the same group by the Scott-Knott test at 5\% probability.

The landraces (V) and experiments (E) had significant effect on the number of pods per plant, but the $\mathrm{V} \times \mathrm{E}$ interaction had no effect on this variable (Table 2). The other two main yield components (number of grains per pod and 100-grain weight) were affected by $\mathrm{V}, \mathrm{E}$, and $\mathrm{V} \times \mathrm{E}$ interaction (Table $2)$. The Baraúna landrace presented high grain yield (Table 3) and small number of pods per plant, but high number of grains per pod and 100-grain weight (Table 4). Similar compensations between yield components occurred with other cowpea varieties and other legumes Ball, Purcell and Vories (2000).

A survey on preferences of consumers regarding characteristics of cowpea grains in two
African countries found that the most relevant characteristic is grain size (LANGTYINTUO et al., 2014). In addition, several international markets, including in Brazil, have preference for large grains; however, classification scales for beans are based on weight not on size (FREIRE FILHO et al., 2012). Freire Filho et al. (2012) suggested the following classification for 100-grain weight $(\mathrm{g})$ : extra-small $(\leq 10)$, small (10.1 to 15$)$, medium (15.1 to 25$)$, large (25.1 to 30$)$, and extra-large $(>30 \mathrm{~g})$. Based on this classification, the varieties evaluated in the present study present medium to large grain sizes, especially Baraúna and Carnaubais varieties, which presented grains with higher weights. 
T. G. G. FREITAS et al.

Table 4. Number of grains per pod and 100-grain weight of traditional cowpea varieties in two experiments ${ }^{1}$.

\begin{tabular}{|c|c|c|c|c|}
\hline \multirow{3}{*}{ Varieties } & \multicolumn{2}{|c|}{ Number of grains per pod } & \multicolumn{2}{|c|}{100 -grain weight } \\
\hline & \multicolumn{2}{|c|}{ Experiments } & \multicolumn{2}{|c|}{ Experiments } \\
\hline & 2013 & 2014 & 2013 & 2014 \\
\hline Baraúna & $15.0 \mathrm{Aa}$ & $14.6 \mathrm{Aa}$ & $26.5 \mathrm{Aa}$ & $23.5 \mathrm{Ab}$ \\
\hline Campo Grande & 16.0 Aa & $12.6 \mathrm{Bb}$ & $21.0 \mathrm{Ca}$ & $18.6 \mathrm{Cb}$ \\
\hline Carnaubais & $15.0 \mathrm{Aa}$ & $13.5 \mathrm{Bb}$ & $24.7 \mathrm{Ba}$ & $24.4 \mathrm{Aa}$ \\
\hline Ceará Mirim & $14.8 \mathrm{Aa}$ & $15.0 \mathrm{Aa}$ & $19.7 \mathrm{Da}$ & $18.3 \mathrm{Cb}$ \\
\hline Itaú & 15.2 Aa & $13.0 \mathrm{Bb}$ & $20.8 \mathrm{Ca}$ & $20.9 \mathrm{Ba}$ \\
\hline José da Penha & $14.2 \mathrm{Ba}$ & $14.8 \mathrm{Aa}$ & $20.4 \mathrm{Ca}$ & $19.7 \mathrm{Ba}$ \\
\hline Lagoa de Pedra & $13.2 \mathrm{Ca}$ & $13.8 \mathrm{Ba}$ & $18.0 \mathrm{Ea}$ & $18.7 \mathrm{Ca}$ \\
\hline Lagoa Salgada & $14.4 \mathrm{Ba}$ & $13.7 \mathrm{Ba}$ & $19.0 \mathrm{Da}$ & $16.6 \mathrm{Db}$ \\
\hline Macaíba & $14.4 \mathrm{Ba}$ & $13.4 \mathrm{Ba}$ & $19.4 \mathrm{Da}$ & $18.7 \mathrm{Ca}$ \\
\hline São Tomé & 14.2 Ba & 14.2 Aa & $16.7 \mathrm{Fa}$ & $16.8 \mathrm{Da}$ \\
\hline Umarizal & $13.2 \mathrm{Cb}$ & 14.6 Aa & $20.2 \mathrm{Ca}$ & $20.2 \mathrm{Ba}$ \\
\hline Upanema & $14.4 \mathrm{Ba}$ & $14.8 \mathrm{Aa}$ & $20.6 \mathrm{Ca}$ & $19.5 \mathrm{Bb}$ \\
\hline CV \% & \multicolumn{2}{|c|}{6.7} & \multicolumn{2}{|c|}{4.3} \\
\hline
\end{tabular}

${ }^{1}$ Means followed by the same uppercase letter in the columns, or same lowercase letter in the rows belong to the same group by the Scott-Knott test at $5 \%$ probability.

Grain yield of most landraces, and mean number of pods per plant of all landraces were higher in the first experiment (2013) (Table 3). However, number of grains per pod and 100-grain weight were similar in both experiments for most landraces (Table 4). This indicates a greater importance of the number of pods per plant to grain yield when compared to the other two main yield components.

The landraces $(\mathrm{V})$, experiments $(\mathrm{E})$, and $\mathrm{V} \times \mathrm{E}$ interaction had significant effect on the three dimensions of the grains (Table 5). Few landraces were grouped in the largest grain size class (Table 6). The Baraúna and Carnaubais landraces in the first experiment (2013), and Baraúna in the second experiment (2014) had higher grain lengths (Table 6). The Carnaubais landrace had higher grain width in both experiments (Table 6). Baraúna, Campo Grande, Carnaubais, and Upanema in 2013, and Campo Grande, and Carnaubais in 2014 had thicker grains.

Table 5. Analysis of variance of grain size data of cowpea landraces in two experiments.

\begin{tabular}{|c|c|c|c|c|}
\hline \multirow{3}{*}{ Source of variation } & \multirow{3}{*}{$\begin{array}{l}\text { Degrees of } \\
\text { freedom }\end{array}$} & \multicolumn{3}{|c|}{ Grain dimensions } \\
\hline & & Length & Width & Thickness \\
\hline & & \multicolumn{3}{|c|}{ Mean squares } \\
\hline Variety (V) & 11 & $3.40 * *$ & $2.69 * *$ & $0.44 * *$ \\
\hline Experiment (E) & 1 & $5.23 * *$ & $0.93 * *$ & $0.50 * *$ \\
\hline $\mathrm{V} \times \mathrm{E}$ & 11 & $0.14^{* *}$ & $0.10^{* *}$ & $0.08 * *$ \\
\hline Blocks within E & 8 & $0.10^{*}$ & $0.06 \mathrm{~ns}$ & $0.11 * *$ \\
\hline Residue & 88 & 0.05 & 0.03 & 0.03 \\
\hline $\mathrm{CV}(\%)$ & & 2.58 & 2.59 & 3.31 \\
\hline
\end{tabular}

ns $=$ not significant; $*=$ significant at $5 \%$, and $* *=$ significant at $1 \%$ by the $\mathrm{F}$ test.

Table 6. Grain size of cowpea landraces in two experiments ${ }^{1}$.

\begin{tabular}{|c|c|c|c|c|c|c|}
\hline \multirow[t]{3}{*}{ Cultivar } & \multirow{2}{*}{\multicolumn{2}{|c|}{$\begin{array}{c}\text { Length (mm) } \\
\text { Experiments }\end{array}$}} & \multirow{2}{*}{\multicolumn{2}{|c|}{$\begin{array}{l}\text { Width }(\mathrm{mm}) \\
\text { Experiments }\end{array}$}} & \multirow{2}{*}{\multicolumn{2}{|c|}{$\begin{array}{c}\text { Thickness (mm) } \\
\text { Experiments }\end{array}$}} \\
\hline & & & & & & \\
\hline & 2013 & 2014 & 2013 & 2014 & 2013 & 2014 \\
\hline Baraúna & $9.5 \mathrm{Ab}$ & $10.2 \mathrm{Aa}$ & $7.1 \mathrm{Ca}$ & $7.0 \mathrm{Da}$ & $5.7 \mathrm{Aa}$ & $5.4 \mathrm{Cb}$ \\
\hline Campo Grande & $8.2 \mathrm{Da}$ & $8.3 \mathrm{Ea}$ & $7.8 \mathrm{Ba}$ & $7.7 \mathrm{Ba}$ & $5.6 \mathrm{Aa}$ & $5.8 \mathrm{Aa}$ \\
\hline Carnaubais & $9.4 \mathrm{Ab}$ & $9.7 \mathrm{Ba}$ & $8.2 \mathrm{Aa}$ & $8.3 \mathrm{Aa}$ & $5.6 \mathrm{Aa}$ & $5.8 \mathrm{Aa}$ \\
\hline Ceará Mirim & $8.5 \mathrm{Cb}$ & $8.8 \mathrm{Da}$ & $6.6 \mathrm{Db}$ & $6.8 \mathrm{Ea}$ & $5.1 \mathrm{Ba}$ & $5.2 \mathrm{Da}$ \\
\hline Itaú & $8.6 \mathrm{Cb}$ & $9.1 \mathrm{Ca}$ & $7.0 \mathrm{Cb}$ & $7.5 \mathrm{Ba}$ & $5.1 \mathrm{Bb}$ & $5.5 \mathrm{Ba}$ \\
\hline José da Penha & $8.7 \mathrm{Cb}$ & $9.4 \mathrm{Ba}$ & $6.9 \mathrm{Cb}$ & $7.3 \mathrm{Ca}$ & $5.1 \mathrm{Bb}$ & $5.4 \mathrm{Ca}$ \\
\hline Lagoa de Pedra & $7.8 \mathrm{~Eb}$ & $8.5 \mathrm{Ea}$ & $6.5 \mathrm{Db}$ & $6.8 \mathrm{Ea}$ & $5.2 \mathrm{Ba}$ & $5.2 \mathrm{Da}$ \\
\hline Lagoa Salgada & $8.2 \mathrm{Db}$ & $8.7 \mathrm{Da}$ & $6.5 \mathrm{Da}$ & $6.6 \mathrm{Ea}$ & $5.2 \mathrm{Ba}$ & $5.3 \mathrm{Da}$ \\
\hline Macaíba & $8.3 \mathrm{Db}$ & $8.7 \mathrm{Da}$ & $7.0 \mathrm{Ca}$ & $7.1 \mathrm{Da}$ & $5.4 \mathrm{Ba}$ & $5.6 \mathrm{Ba}$ \\
\hline São Tomé & $7.6 \mathrm{~Eb}$ & $8.1 \mathrm{Fa}$ & $6.3 \mathrm{Ea}$ & $6.4 \mathrm{Fa}$ & $5.1 \mathrm{Ba}$ & $5.1 \mathrm{Da}$ \\
\hline Umarizal & $9.1 \mathrm{Ba}$ & $9.1 \mathrm{Ca}$ & $7.0 \mathrm{Ca}$ & $7.2 \mathrm{Da}$ & $5.3 \mathrm{Ba}$ & $5.4 \mathrm{Ca}$ \\
\hline Upanema & $8.3 \mathrm{Da}$ & $8.5 \mathrm{Ea}$ & $7.2 \mathrm{Ca}$ & $7.4 \mathrm{Ca}$ & $5.5 \mathrm{Aa}$ & $5.6 \mathrm{Ba}$ \\
\hline
\end{tabular}

${ }^{1}$ Means followed by the same uppercase letter in the columns, or same lowercase letter in the rows belong to the same group by the Scott-Knott test at 5\% probability. 
The Baraúna and Carnaubais landraces had the highest grain yields in both experiments (Table 3 ). Therefore, these are the most promising landraces for direct use by farmers and breeding programs. However, Campo Grande variety in the first experiment (2013), and José da Penha, Lagoa de Pedra, Umarizal, and Umarema in the second experiment (2014) also showed high yields. These varieties could also be useful for farmers, either for direct use or after genetic improvement. However, direct use of a variety by farmers requires considering several other characteristics. Landraces that are used by farmers have been evaluated and have a high chance of being accepted because they present other desirable characteristics.

Landraces can also be used in breeding programs for varied purposes, including grain yield, resistance to drought, and photosynthetic rate (HALL; GRANTZ, 1980; PADI; EHLERS, 2007; BIRADAR; SALIMATH; PATIL, 2010). These programs can use hybridization with improved cultivars (PADI; EHLERS, 2007; BIRADAR; SALIMATH; PATIL, 2010) or subject these traditional varieties to selection (HALL; GRANTZ, 1980; HEGDE; MISHRA, 2009) due to their variability from mixtures of seeds, mutations, and natural crosses. Mass selection and individual selection of plants with progeny testing are promising for these varieties (FREIRE FILHO et al., 2012). Regarding hybridization, Padi and Ehlers (2007) concluded that population, and single seed descent methods would be more efficient than the genealogical method for the development of cowpea cultivars from landraces.

The $\mathrm{k}$ values used for the path analyses were 0.1279 (2013), and 0.1021 (2014); coefficients of determination were 0.78 (2013) and 0.87 (2014); condition numbers were 25.1 (2013), and 29.4 (2014); residual effects were 0.47 (2013), and 0.36 (2014); and determinants of the $X^{\prime} X$ matrix were 0.06 (2013), and 0.02 (2014). Therefore, the coefficients of determination of the path analyses were high, even higher than those found in other studies (ALMEIDA et al., 2014; SANTOS et al., 2014). This indicates that much of the variation of the main characteristic (grain yield) was determined by explanatory characteristics.

The values of the variance inflation factor (VIF) were below 10 in both experiments (Table 7). According to Neter, Wasserman and Kutner (1983), the VIF can be used to detect multicollinearity. Values of VIF above 10 may indicate that the regression coefficients associated with these values have estimates that are strongly influenced by multicollinearity (NETER; WASSERMAN; KUTNER, 1983). Thus, the results obtained in the present study indicate that multicollinearity bias was low in the regression analysis and these results are, therefore, reliable estimates (CARVALHO, CRUZ, 1996).

In general, only the direct explanatory effects of the number of pods per plant on grain yield in the two experiments were similar, and this characteristic presented the greatest direct effect (Table 7). Therefore, an increased expression of this characteristic can affect positively grain yield. These results agree with those observed in other studies (MISHRA; DASH, 2009, NWOFIA; OGBONNA; AGBO, 2013, HITIKSHA; ACHARYA; SHEETAL, 2014, SAPARA; JAVIA, 2014). These observations are important because the number of pods is relatively easier to evaluate when compared to grain yield, which requires the pods to be threshed using processes that can be laborious.

The direct effects of number of grains per pod per plant, and grain width and thickness on grain yield were positive in both experiments. However, the effect of the number of grains per pod was slightly higher in the first experiment, and the effects of the other two characteristics were greater in the second experiment (Table 7). The direct effects of 100 -grain weight, and grain length on grain yield were positive or negative, depending on the experiment (Table 7). The differences in the effects of the characteristics evaluated in the two experiments on grain yield indicate that the path analysis should be carried out for each experiment separately when conducting two or more experiments because of possible differences in the results of each experiment.

The evaluation of cowpea grain yield through yield components should consider genetic (UMAHARAN; ARIYANAYAGAM; HAQUE, 1997; SHIMELIS; SHIRINGANI, 2010) and environmental factors. Environmental factors affect the crop at different times of the cycle of cereals (PELTONEN-SAINIO et al., 2007). Pod formation and number of grains per pod depend on environmental factors before anthesis, and grain weight depend on environmental factors after anthesis. Cowpea plants produce flowers continuously for a certain period until flowering, thus, environmental factors would affect these three main production components, simultaneously.

The genetic complexity of the yield components (SHIMELIS; SHIRINGANI, 2010; ROMANUS; HUSSEIN; MASHELA, 2008), considering the interaction between genetic and environmental factors affecting the cowpea cycle, can explain the differences found in the effects of production components on grain yield when comparing the two experiments, and comparing these experiments with other studies. It also explains the differences in the characteristics found as more relevant to grain yield by different methods of analysis (LEILAH; AL-KHATEEB, 2005). 
T. G. G. FREITAS et al

Table 7. Association effects (estimated under multicollinearity, EM) of characteristics of 12 traditional varieties of cowpea on grain yield in two experiments, and their respective values of variance inflation factor (VIF).

\begin{tabular}{|c|c|c|c|c|c|}
\hline \multirow[t]{2}{*}{ Characteristic } & \multirow[t]{2}{*}{ Association effects } & \multicolumn{2}{|c|}{$\begin{array}{c}\text { First experiment } \\
(2013)\end{array}$} & \multicolumn{2}{|c|}{$\begin{array}{c}\text { Second experiment } \\
(2014) \\
\end{array}$} \\
\hline & & EM & VIF & EM & VIF \\
\hline \multirow{8}{*}{$\begin{array}{c}\text { Number of pods } \\
\text { per plant }\end{array}$} & Direct & 0.717 & 1.649 & 0.777 & 2.528 \\
\hline & Indirect via: & & & & \\
\hline & Number of grains per pod & -0.138 & 0.255 & 0.154 & 1.400 \\
\hline & 100 -grain weight & -0.183 & 1.035 & 0.008 & 0.360 \\
\hline & Grain length & 0.049 & 0.490 & -0.036 & 0.757 \\
\hline & Grain width & -0.146 & 0.844 & -0.026 & 0.302 \\
\hline & Grain thickness & -0.036 & 0.102 & -0.002 & 0.368 \\
\hline & Total & 0.353 & & 0.954 & \\
\hline \multirow{8}{*}{$\begin{array}{l}\text { Number of grains } \\
\text { per pod }\end{array}$} & Direct & 0.325 & 1.791 & 0.207 & 3.073 \\
\hline & Indirect via: & & & & \\
\hline & Number of pods per plant & -0.305 & 0.235 & 0.578 & 1.151 \\
\hline & 100 -grain weight & 0.144 & 0.634 & 0.007 & 0.310 \\
\hline & Grain length & -0.007 & 0.010 & -0.038 & 0.869 \\
\hline & Grain width & 0.070 & 0.193 & -0.010 & 0.046 \\
\hline & Grain thickness & 0.069 & 0.371 & 0.000 & 0.003 \\
\hline & Total & 0.337 & & 0.765 & \\
\hline \multirow{8}{*}{100 -grain weight } & Direct & 0.380 & 5.639 & -0.028 & 5.715 \\
\hline & Indirect via: & & & & \\
\hline & Number of pods per plant & -0.346 & 0.303 & -0.215 & 0.159 \\
\hline & Number of grains per pod & 0.123 & 0.201 & -0.053 & 0.166 \\
\hline & Grain length & -0.103 & 2.207 & 0.064 & 2.400 \\
\hline & Grain width & 0.297 & 3.490 & 0.099 & 4.205 \\
\hline & Grain thickness & 0.112 & 0.974 & 0.006 & 2.487 \\
\hline & Total & 0.511 & & -0.131 & \\
\hline \multirow{8}{*}{ Grain length } & Direct & -0.117 & 3.647 & 0.074 & 3.963 \\
\hline & Indirect via: & & & & \\
\hline & Number of pods per plant & -0.296 & 0.222 & -0.374 & 0.483 \\
\hline & Number of grains per pod & 0.019 & 0.005 & -0.107 & 0.674 \\
\hline & 100 -grain weight & 0.333 & 3.412 & -0.024 & 3.460 \\
\hline & Grain width & 0.261 & 2.696 & 0.081 & 2.838 \\
\hline & Grain thickness & 0.068 & 0.361 & 0.005 & 1.786 \\
\hline & Total & 0.253 & & -0.338 & \\
\hline \multirow{8}{*}{ Grain width } & Direct & 0.319 & 5.122 & 0.105 & 5.753 \\
\hline & Indirect via: & & & & \\
\hline & Number of pods per plant & -0.328 & 0.272 & -0.196 & 0.133 \\
\hline & Number of grains per pod & 0.071 & 0.067 & -0.020 & 0.025 \\
\hline & 100 -grain weight & 0.353 & 3.842 & -0.026 & 4.177 \\
\hline & Grain length & -0.096 & 1.920 & 0.057 & 1.955 \\
\hline & Grain thickness & 0.124 & 1.195 & 0.006 & 2.921 \\
\hline & Total & 0.484 & & -0.064 & \\
\hline \multirow{8}{*}{ Grain thickness } & Direct & 0.163 & 2.629 & 0.007 & 4.318 \\
\hline & Indirect via: & & & & \\
\hline & Number of pods per plant & -0.159 & 0.064 & -0.250 & 0.215 \\
\hline & Number of grains per pod & 0.137 & 0.253 & -0.006 & 0.002 \\
\hline & 100 -grain weight & 0.261 & 2.088 & -0.024 & 3.291 \\
\hline & Grain length & -0.049 & 0.501 & 0.053 & 1.639 \\
\hline & Grain width & 0.243 & 2.327 & 0.095 & 3.892 \\
\hline & Total & 0.616 & & -0.124 & \\
\hline
\end{tabular}




\section{CONCLUSIONS}

The Baraúna and Carnaubais landraces were the most productive in both experiments. The Campo Grande landrace had the highest grain yield in the experiment carried out in the dry season (2013) with irrigation.

The José da Penha, Lagoa de Pedra, Umarizal, and Upanema landraces had the greatest grain yields in the experiment carried out in the rainy season (2014).

The number of pods per plant was the characteristic that had greater direct effect on grain yield.

\section{REFERENCES}

AL-FALIH, A. M. K. Factors affecting the efficiency of symbiotic nitrogen fixation by Rhizobium. Pakistan Journal of Biological Sciences, v. 5, n. 11, p. 1277-1293, 2002.

ALMEIDA, W. S. et al. Correlation and path analysis in components of grain yield of cowpea genotypes. Revista Ciência Agronômica, v. 45, n. 4, p. 726-736, 2014.

BALL, R. A.; PURCELL, L. C.; VORIES, E. D. short-season soybean yield compensation in response to population and water regime. Crop Science, v. 40, n. 4, p. 1070-1078, 2000

BELANE, A. K.; DAKORA, F. D. Symbiotic $\mathrm{N}_{2}$ fixation in 30 field-grown cowpea (Vigna unguiculata L. Walp.) genotypes in the Upper West Region of Ghana measured using ${ }^{15} \mathrm{~N}$ natural abundance. Biology and Fertility of Soils, v. 46, n. 2, p. 191-198, 2010.

BERTINI, C. H. C. M. et al. Análise multivariada e índice de seleção na identificação de genótipos superiores de feijão-caupi. Acta Scientiarum: Agronomy, v. 32, n. 4, p. 613-619, 2010.

BIRADAR, S.; SALIMATH, P. M.; PATIL, B. C. Land race as a source for improving photosynthetic rate and productivity in cowpea (Vigna unguiculata W.). Eletronic Journal of Plant Breeding, v. 1, n. 4, p. 872-877, 2010.

BOUKAR, O.; FATOKUN, C. Strategies in cowpea breeding. In: ZERIHUN, T. (Ed.). New approaches to plant breeding of orphan crops in Africa. Rome: FAO, 2009. cap. 6, p. 69-92.

BRESEGHELlO, F.; COELHO, A. S. Traditional and modern plant breeding methods with examples in rice (Oryza sativa L.). Journal of Agricultural and Food Chemistry, v. 29, n. 35 , p. $8277-8286$, 2013.

CARMO FILHO, F.; OLIVEIRA, O. F. de Mossoró: um município do semi-árido nordestino. Mossoró: Fundação Guimarães Duque/ESAM, 1989. 62 p. (Coleção mossoroense, 672).

CARVALHO, S. P.; CRUZ, C. D. Diagnosis of multicollinearity: assessment of the condition of correlation matrices used in genetic studies. Revista Brasileira de Genética, v. 19, n. 3, p. 479-484, 1996.

COBBINAH, F. A.; ADDO-QUAYE, A. A.; ASANTE, I. K. Characterization, evaluation and selection of cowpea (Vigna unguiculata (L.) Walp) accessions with desirable traits from eight regions of Ghana. Journal of Agricultural and Biological Science, v. 6, n. 7, p. 21-32, 2011.

CRUZ, C. D. GENES - A software package for analysis in experimental statistics and quantitative genetics. Acta Scientiarum Agronomy, v. 35, n. 3, p. 271-276, 2013.

EMPRESA BRASILEIRA DE PESQUISA AGROPECUÁRIA - EMBRAPA, Centro Nacional de Pesquisa do Solo. Sistema Brasileiro de classificação de solos. 3. ed. Brasília, DF: Serviço de Produção de Informação, 2013. 353 p.

FOOD AND AGRICULTURE ORGANIZATION OF THE UNITED NATIONS - FAO. Soil map of the world; revised legend. Rome: UNESCO, 1988. $119 \mathrm{p}$.

FREIRE FILHO, F. R. Feijão-caupi no Brasil: produção, melhoramento genético, avanços e desafios. Teresina, PI: Embrapa, 2011. 84 p.

FREIRE FILHO, F. R. et al. Adaptabilidade e estabilidade da produção de grãos de caupi enramador de tegumento mulato. Pesquisa Agropecuária Brasileira, v. 38, n. 5, p. 91-598, 2003

FREIRE FILHO, F. R. et al. Production, breeding and potential of cowpea crop in Brazil. Teresina, PI: Embrapa, 2012. 54 p. (Documentos, 216).

FREITAS, T. G. G. et al. Green bean yield and path analysis in cowpea landraces. Revista Caatinga, $v$. 29 , n. 4 , p. $866-877,2016$

HALL, A. E.; GRANTZ, D. A. Drought resistance of cowpea improved by selecting for early appearance of mature pods. Crop Science, v. 21, n. 3, p. 461461,1980 . 
HEGDE, V. S.; MISHRA, S. K. Landraces of cowpea, Vigna unguiculata (L.) Walp., as potential sources of genes for unique characters in breeding. Genetics resources and Crop Evolution, v. 56, n. 5, p. 615-627, 2009.

HITIKSHA, K. P.; ACHARYA, R. R.; SHEETAL, R. P. Interrelationship among green pod yield and its yield contributing characters and biochemical characters vegetable cowpea [Vigna unguiculata (L.) Walp.]. Trends in Biosciences, v. 7, n. 23, p. 39723976, 2014.

LANGYINTUO, A. S. et al. Consumer preferences for cowpea in Camerron and Ghana. Agricultural Economics, v. 30, n. 3, p. 203-213, 2014.

LEILAH, A. A.; AL-KHATEEB, S. Statistical analysis of wheat yield under drought conditions. Journal of Arid Environments, v. 61, n. 3, p. 483 496, 2005.

MAKOI, J. H. J. R.; CHIMPHANGO, S. B. M.; DAKORA, F. D. Effect of legume plant density and mixed culture on symbiotic $\mathrm{N}_{2}$ fixation in five cowpea (Vigna unguiculata L. Walp.) genotypes in South Africa. Symbiosis, v. 48, n. 1, p. 57- 67, 2009.

MISHRA, H. N.; DASH, S. R. A study on variability, character association and path analysis for green pod yield in yard long bean [Vigna unguiculata subsp sesquipedalis (L.) Verdcourt]. Vegetable Science, v. 36, n. 3, p. 319-322, 2009.

NETER, J.; WASSERMAN, W.; KUTNER, M. H. Applied linear regression models. Homewood: Richard D. Irwin Inc., 1983. 547 p.

NOGUEIRA, D. A.; PEREIRA, G. M. Desempenho de testes para homogeneidade de variâncias em delineamento inteiramente casualizado. Sigmae, v. 2, n. 1, p. 7-22. 2013.

NWOFIA, G. E.; OGBONNA, N. D.; AGBO, C. U. Path analysis and heritability estimates of yield and yield components in vegetable cowpea as influenced by planting season. American-Eurasian Journal of Agriculture \& Environmental Sciences, v. 13, n. 9, p. 1283-1289, 2013.

PADI, F. K.; EHLERS, J. D. Effectiveness of early generation selection in cowpea for grain yield and agronomic characteristics in semiarid West Africa. Crop Science, v. 48, n. 2, p. 533-540, 2008.

PEKSEN, A. Fresh pod yield and some pod characteristics of cowpea (Vigna unguiculata L. Walp.) genotypes from Turkey. Asian Journal of Plant Sciences, v. 3, n. 3, p. 269-273, 2004.
PELTONEN-SAINIO, $P$. et al. Grain number dominates grain weight in cereal yield determination: evidence basing on 30 years' multi-location trials. Field Crops Research, v. 100, n. 2-3, p. 179-188, 2007.

ROMANUS, K. G.; HUSSEIN, S.; MASHELA, W. P. Combining ability analysis and association of yield and yield components among selected cowpea lines. Euphytica, v. 162, n. 2, p. 205-210, 2008.

SANTOS, A. et al. Correlations and path analysis of yield components in cowpea. Crop Breeding and Applied Biotechnology, v. 14, n. 2, p. 82-87, 2014.

SAPARA, G. K.; JAVIA, R. M. Correlation and path analysis in vegetable cowpea (Vigna unguiculata L.). International Journal of Plant Sciences, v. 9, n. 1, p. 138-141, 2014.

SHIMELIS, H.; SHIRINGANI, R. Variance components and heritabilities of yield and agronomic traits among cowpea genotypes. Euphytica, v. 176, n. 3 , p. $383-389,2010$.

TAN, H. et al. A review of molecular markers applied in cowpea (Vigna unguiculata L. Walp.) breeding. Journal of Life Sciences, v. 6, n. 1, p. 1190-1199, 2012.

TOEBE, M.; CARGNELUTTI FILHO, A. Multicollinearity in path analysis of maize (Zea mays L.). Journal of Cereal Science, v. 57, n. 3, p. 453462, 2013.

UMAHARAN, P.; ARIYANAYAGAM, R. P.; HAQUE, S. Q. Genetic analysis of yield and its components in vegetable cowpea (Vigna unguiculata L.Walp.). Euphytica, v. 96, n. 2, p. 207-213, 1997.

WRIGHT, S. Correlation and causation. Journal of Agricultural Research, v. 20, n. 7, p. 557-585, 1921.

YOSEPH, T. Performance evaluation of cowpea (Vigna unguiculata L.) varieties under moisture conservation practices for yield and yield components at Alduba, Southern Ethiopia. Journal of Natural Sciences Research, v. 4, n. 7, p. 7-11, 2014. 